\title{
Texar Federal Credit Union: Where Your Friends Are
}

Larry R. Davis, Texas A \& M University-Texarkana, USA

Joan Brumm, Texas A \& M University-Texarkana, USA

Charles McDonald, Jr., Texas A \& M University-Texarkana, USA

\begin{abstract}
TEXAR Federal Credit Union (formerly Bowie County Teachers Credit Union, Bowie-Cass Teachers Credit Union, and the Teachers Federal Credit Union) has been, from inception in 1951, a provider of a broad range of financial services to its members, primarily in Texarkana, Texas, and Arkansas and the surrounding areas. The credit union experienced normal growth over the years as it progressed through major name changes, especially to TEXAR in 2001. Another significant milestone was the decision to launch a major building program that concluded with moving into a new, large, and modern building in 2003.
\end{abstract}

As the national economy went into a recession in 2008, the states of Texas and Arkansas experienced economic slowdowns that were not as significant as the changes that were reflected in the economic indicators at the national level or those experienced by other states that were much more severely affected. The Texarkana area economy was moderately affected by slowdowns in lending, especially for housing, automobiles, and other durable products. There was additional impact by an elevation in member loan defaults.

Another significant occurrence, not related to the local economy, was the failure of U.S. Central Federal Credit Union and Western Corporate (WesCorp) Federal Credit Union and the financial losses of Southwest Corporate Federal Credit Union. Similar to the Federal Deposit Insurance Corporation that insures losses in the banking industry, the National Credit Union Share Insurance Fund (NCUSIF) insures losses among credit unions. To help cover the losses of U.S. Central and WesCorp, TEXAR was assessed approximately $\$ 750,000$ and because of the losses at Southwest Corporate, it was assessed approximately $\$ 700,000$. That is the essence of this case.

Keywords: Credit Unions; Financial Industry; Financial Ratio Analysis; Marketing Strategy; Strategic Planning

\section{INTRODUCTION}

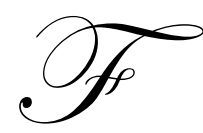

rom their origins, credit unions were formed under statutory provisions as unique not-for-profit financial institutions by an organized group whose members pool their assets through deposits to provide loans and other financial services solely to each other. They are operated by mostly volunteer boards of directors. When formed according to the provisions of the Federal Credit Union Act of 1934, credit unions are chartered and regulated by the National Credit Union Administration (NCUA). They also insure savings in federal and most state-chartered credit unions through the National Credit Union Share Insurance Fund (NCUSIF), a federal fund that is backed by the United States government.

The history of credit unions began in 1844 with a group of weavers in Rochdale, England, who established the Rochdale Society of Equitable Pioneers. The weavers sold shares to members to raise the capital necessary to buy goods at lower-than-retail prices and then sold the goods at a saving to members. In doing so, they became the first credit union. 
The movement spread to Germany in 1850 , the first home of credit unions as we know them today, and to Levis, Quebec, Canada, in 1901, where Alphonse Desjardins organized La Caisse Populaire de Levis. He recognized the outrageous interest being charged by loan sharks and organized the credit union to provide relief to the working class. In 1909, he helped a group of Franco-American Catholics in Manchester, New Hampshire, organize St. Mary's Cooperatives Credit Association - the first credit union in the U. S.

Spurred by the attention of Edward Filene, a merchant and philanthropist, and Pierre Jay, the Mass Banking Commissioner, the Massachusetts Credit Union Act became law April 15, 1909. The act served as a basis for subsequent state credit union laws and the Federal Credit Union Act.

President Roosevelt signed the Federal Credit Union Act in 1934, forming a national system to charter and supervise federal credit unions. Credit Unions grew steadily in the 1940's and 1950's. By 1960, credit union membership amounted to more than 6 million in over 10,000 institutions. In 1970, the NCUA became an independent federal agency and the NCUSIF was formed to insure member's deposits.

\section{BACKGROUND}

\section{TEXAR Federal Credit Union}

The financial institution that is now TEXAR Federal Credit Union was established as Bowie County Teachers Credit Union in 1951, became Bowie-Cass Teachers Credit Union in 1964, the Teachers Federal Credit Union in 1974, and, subsequently, TEXAR Federal Credit Union in 2001. An organization meeting took place on August 10, 1951 where procedures were implemented and documents were prepared to apply for a Texas Charter. A five-member board of directors would be formed and membership subscriptions were committed. Charter number 176 was granted to Bowie County Teachers Credit Union on September 7, 1951.

The first board of directors was selected at a meeting on that day which, in turn, elected four officers: president, vice president, treasurer, and secretary. The first annual meeting was held on January 10, 1952 with 21 of 40 members attending.

At the 1954 annual meeting, the board of directors was increased to seven members. The field of membership was also expanded from only school employees to include spouses, siblings, children, and parents of school employees. In 1964, the field of membership was again amended to include "employees of public schools of Bowie and Cass Counties, State of Texas, employees of the credit union, auxiliary employees, members of their immediate families, and organizations of such persons." In 1954, assets were $\$ 55,000$ and membership was 224. Exhibit 1 shows the subsequent growth of assets and membership.

Exhibit 1: TEXAR Federal Credit Union - Asset \& Membership Growth

\begin{tabular}{|c|c|c|}
\hline Year & Assets & Membership \\
\hline 1951 & 4,657 & 40 \\
\hline 1955 & 108,120 & 276 \\
\hline 1960 & 358,829 & 620 \\
\hline 1965 & 892,896 & 1,187 \\
\hline 1970 & $2,057,727$ & 1,798 \\
\hline 1975 & $8,133,245$ & 3,957 \\
\hline 1980 & $13,605,564$ & 5,724 \\
\hline 1985 & $15,321,947$ & 5,761 \\
\hline 1990 & $37,699,473$ & 7,400 \\
\hline 2000 & $59,791,990$ & 12,412 \\
\hline 2005 & $86,594,988$ & 15,497 \\
\hline 2010 & $159,008,181$ & 25,183 \\
\hline
\end{tabular}

Source: TEXAR FCU Records 
J. H. Calvert had served as part time manager until he became the full time manager in 1969. The following year he retired and was replaced by Frank Cardin in that position. The by-laws were amended in 1974 to change the name from Bowie-Cass Teachers Credit Union to the Teachers Federal Credit Union.

In 1976, two new services were added - Individual Retirement Accounts (IRA's) and Share Drafts (Checking Accounts). A new building was also completed that year on Kennedy Lane, Texarkana, Texas. On October 21, 1977, Frank Cardin resigned to be followed by Alvin Jackson as president in December, 1977. Exhibit 2 presents the CEO progression for the credit union.

Exhibit 2: TEXAR Federal Credit Union - Management Progression

\begin{tabular}{|l|c|c|}
\hline \multicolumn{1}{|c|}{ Title } & Name & Period Of Service \\
\hline Part-Time Manager & J. H. Calvert & $7 / 18 / 1969-7 / 1970$ \\
\hline Manager & J. H. Calvert & $7 / 1970-10 / 21 / 1977$ \\
\hline Manager & Frank Cardin & $12 / 05 / 1977-7 / 31 / 1978$ \\
\hline President & Alvin Jackson & $8 / 01 / 1978-10 / 1978$ \\
\hline Interim Manager & Newton Thompson & $10 / 1978-1 / 1984$ \\
\hline Manager & Newton Thompson & $2 / 26 / 1984-12 / 31 / 1999$ \\
\hline President & Joe Thornton & $1 / 1 / 2000-$ Present \\
\hline President \& CEO & Kelly Mitchell & \\
\hline
\end{tabular}

Source: TEXAR FCU Records

During the third quarter of 1983 , several problems were identified within the institution. Undivided Earnings suffered negative balance, contingent losses in real estate loans were identified, and two branch offices were identified for possible closure. The credit union converted from an on-line to an in-house computer system in August 1983. In February 1984, one of the branches was closed.

In 1987, the organization went through a remodeling program, the Atlanta (Texas) branch was built, and the field of membership was expanded by the addition of several new Separate Employee Groups (SEG's). Financial services were expanded and the name, TEXAR Federal Credit Union, was implemented in March 2001. A large, new modern, building was completed and moved into in January 2003. Currently, TEXAR has $\$ 240$ million in assets, has five branches, and 85 employees.

\section{Recent Events}

As the national economy went into a recession in 2008, the states of Texas and Arkansas experienced economic slowdowns that were not as significant as the changes that were reflected in the economic indicators at the national level or those experienced by other states that were much more severely affected. While the national unemployment rate approached $10 \%$, the Texas unemployment peaked at $7.6 \%$. The Bowie County, Texas, unemployment rate, which includes Texarkana, peaked at a less severe 6.7\%. The Texarkana area economy was moderately affected by slowdowns in lending, especially for housing, automobiles, and other durable products. There was additional impact by an elevation in member loan defaults.

The most significant occurrence that was not related to the local economy was the failure of U.S. Central Federal Credit Union and Western Corporate (WesCorp) Federal Credit Union and the financial losses of Southwest Corporate Federal Credit Union. Similar to the Federal Deposit Insurance Corporation that insures losses in the banking industry, the National Credit Union Share Insurance Fund (NCUSIF) insures losses among credit unions. To help cover the losses of U.S. Central and WesCorp, TEXAR was assessed approximately $\$ 750,000$ and because of the losses at Southwest Corporate, it was assessed approximately $\$ 700,000$. These assessments, in addition to the moderate slowdown in business because of the local economy starting in 2008, had an adverse effect on TEXAR's undivided earnings. A major challenge for the TEXAR management team was to establish a plan to deal with these economic challenges and the consequences of the assessments. 


\section{TEXAR Federal Credit Union Mission Statement}

The TEXAR Federal Credit Union mission statement that reflects the philosophy of management is "to serve the financial needs of our members". The statement, although rather simple, is reviewed by the board of directors every year and continues to be readopted.

\section{Competition}

The significant major area of competition of TEXAR is considered to be Red River Federal Credit Union that operates in the same area and has assets of approximately $\$ 400$ million. Mil-Way Federal Credit Union and Domino Federal Credit Union also operate in the area, but are smaller and serve more specialized memberships. Area banks include Region's Bank, BanCorp South, Wells Fargo Bank, and several smaller banks that have entered the local market in the last five years.

Exhibit 3 present the market wants/needs of its members as determined by TEXAR research.

Exhibit 3: TEXAR Federal Credit Union - Member Wants/Needs

\begin{tabular}{|l|}
\hline Members Wants/Needs \\
\hline 1. $\quad$ Low Interest Loans \\
2. High Interest on Deposits \\
3. $\quad$ Convenience of Financial Products and Services \\
\hline TEXAR FCU Wants/Needs \\
\hline 1. Low Cost of Funds \\
2. High Interest on Investments \\
3. Economic/Market Stability \\
4. Fair Regulations \\
Source: TEXAR FCU Research
\end{tabular}

TEXAR performed a SWOT analysis of the institution in 2010 and Exhibit 4 presents what the research identified as its strengths, weaknesses, opportunities and threats.

Exhibit 4: TEXAR Situation Assessment - SWOT Assessment 2010

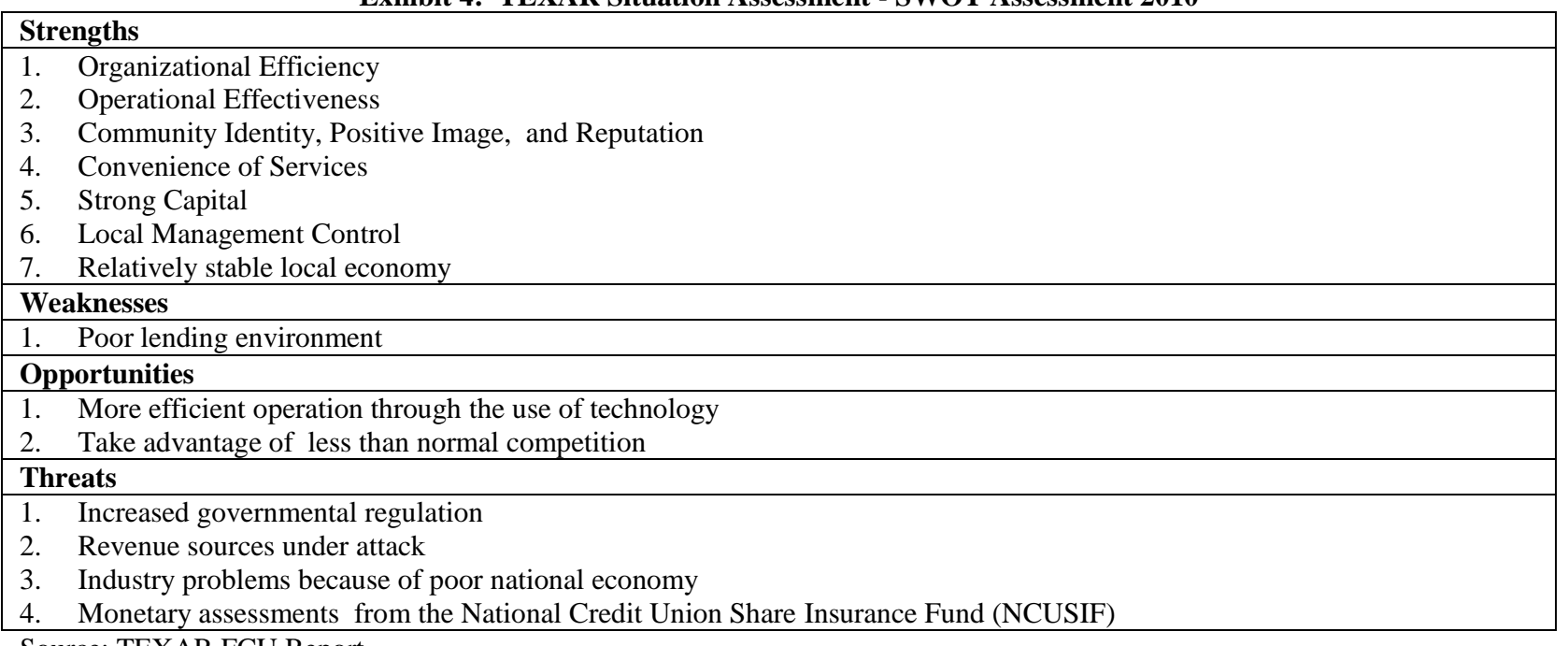

Source: TEXAR FCU Report

\section{Distinct Competency}

Distinct competencies are those processes and attributes of an organization creating a unique position relative to its competitors among the targeted market. This mixture should be a recipe for success that, in 
combination, creates a unique persona for TEXAR Federal Credit Union that members view as positive and desirable. In short, they make an institution different and better.

\section{Distinct Competency Set for TEXAR Federal Credit Union}

1. Operational Effectiveness

2. Organizational Efficiency

3. Community Identity, Positive Image, and Reputation

4. $\quad$ Convenience of Services

5. Strong Capital

6. Local Operational/Management Control

\section{Key Opportunities}

1. More efficient operation through the use of technology

2. Take advantage of less than normal competition

3. Capitalize on positive community image

\section{THE CREDIT UNION INDUSTRY}

\section{Industry Financial Data}

TEXAR is part of the three-digit SIC code 606 industry grouping which includes all credit unions, both federally chartered and not federally chartered. Credit unions are part of a larger two digit industry grouping which includes all depositary institutions. Selected financial ratios for the credit union industry are presented in Exhibit 5. Industry data were obtained from CUDATA.COM Online Financial Performance Measurement System. CUDATA is an online service that gathers credit union data and organizes it into analytical reports.

Exhibit 5: Credit Union National Statistics as of December 31, 2009

\begin{tabular}{|c|c|c|c|}
\hline & 2007 & 2008 & 2009 \\
\hline \multicolumn{4}{|l|}{ Membership } \\
\hline \# of Members & $88,500,886$ & $89,919,778$ & $91,192,455$ \\
\hline \# of New Members (YTD) & $1,086,216$ & $1,418,892$ & $1,272,677$ \\
\hline$\%$ Increase & & $1.6 \%$ & $1.42 \%$ \\
\hline \multicolumn{4}{|l|}{ Assets } \\
\hline Total Assets \$ (In Millions) & $\$ 770,099.73$ & $\$ 823,662.49$ & $\$ 896,824.20$ \\
\hline Total Assets Growth (YTD) & $6.04 \%$ & $6.96 \%$ & $8.88 \%$ \\
\hline Return On Assets (ROA)-Annualized & $0.64 \%$ & $-0.01 \%$ & $0.18 \%$ \\
\hline \multicolumn{4}{|l|}{ Net Worth } \\
\hline Net Worth \$ (In Millions) & $\$ 88,125.49$ & $\$ 87,751.56$ & $\$ 88,737.22$ \\
\hline Net Worth Ratio & 11.44 & 10.65 & 9.89 \\
\hline \multicolumn{4}{|l|}{ Total Loans } \\
\hline Total Loans (\$) (In Millions) & $\$ 538,602.81$ & $\$ 574,753.63$ & $\$ 580,454.24$ \\
\hline Total Loans (\$) Growth (YTD) & $6.54 \%$ & $6.71 \%$ & $0.99 \%$ \\
\hline Yield on Loans (Annualized) & $6.74 \%$ & $6.61 \%$ & $6.29 \%$ \\
\hline \multicolumn{4}{|l|}{ Loan Delinquency } \\
\hline Delinquent Loans To Total Loans & $0.93 \%$ & $1.37 \%$ & $1.83 \%$ \\
\hline Net Charge Offs To Avg Loan & $0.5 \%$ & $0.84 \%$ & $1.21 \%$ \\
\hline \multicolumn{4}{|l|}{ Deposits } \\
\hline Total Deposits (\$) (In Mil) & $\$ 646,819.67$ & $\$ 691,764.55$ & $\$ 763,341.59$ \\
\hline Total Deposits (\$) Growth (YTD) & $5.12 \%$ & $6.95 \%$ & $10.35 \%$ \\
\hline \multicolumn{4}{|l|}{ Branch Delivery } \\
\hline Number of CUs & 8,268 & 7,968 & 7,710 \\
\hline \# of Branch Offices & 20,848 & 21,403 & 21,341 \\
\hline
\end{tabular}

Source: CUDATA.COM Online Financial Performance Measurement System 


\section{TEXAR Federal Credit Union}

Exhibits 6 through 8 contain financial and operating information for TEXAR Federal Credit Union for 2007, 2008, and 2009.

Exhibit 6: TEXAR Federal Credit Union - Delinquent Loans, Loan Charge Offs And Recoveries

\begin{tabular}{|l|c|c|c|}
\hline & \multicolumn{2}{|c|}{ Total Reportable Delinquency (Amount) } \\
\hline Delinquent Loans & $\mathbf{2 0 0 7}$ & $\mathbf{2 0 0 8}$ & $\mathbf{2 0 0 9}$ \\
\hline Unsecured Credit Card Loans & 2,397 & $-0-$ & 13,027 \\
\hline Fixed Rate(Hybrid/Balloon > 5 yrs) & $-0-$ & $-0-$ & 102,619 \\
\hline 1st Mortgage Fixed Adjustable Rate & 186,529 & 203,362 & 32,885 \\
\hline All Other Loans & 853,904 & 908,176 & $1,165,975$ \\
\hline Total Delinquent Loans & $1,042,830$ & $1,111,538$ & $1,314,506$ \\
\hline & & & \\
\hline YTD Loans Charged Off & & & \\
\hline Unsecured Credit Card Loans & 37,184 & 29,306 & 46,075 \\
\hline All Other Loans & 759,444 & 992,409 & $1,075,341$ \\
\hline Total & 796,628 & $1,021,715$ & $1,121,416$ \\
\hline Soul
\end{tabular}

Source: www.creditunions.com

Exhibit 7: TEXAR Federal Credit Union - Statement Of Financial Condition

\begin{tabular}{|c|c|c|c|}
\hline Interest Income & 2007 & 2008 & 2009 \\
\hline Interest on Loans (Gross-before interest refunds) & $11,847,790$ & $12,620,739$ & $12,375,280$ \\
\hline Income from Investments & 793,929 & 789,055 & 425,831 \\
\hline TOTAL INTEREST INCOME & $12,641,719$ & $13,409,794$ & $12,801,111$ \\
\hline \multicolumn{4}{|l|}{ Interest Expense } \\
\hline Dividends on Shares & $4,770,556$ & $4,825,871$ & $3,355,729$ \\
\hline Interest on Borrowed Money & 561,918 & 737,576 & 496,863 \\
\hline TOTAL INTEREST EXPENSE & $5,332,474$ & $5,563,447$ & $3,852,592$ \\
\hline Provision for Loan Losses (PLL) & 685,715 & 841,836 & $1,190,830$ \\
\hline Net Interest Income After PLL & $6,623,530$ & $7,004,511$ & $7,757,689$ \\
\hline \multicolumn{4}{|l|}{ Non-Interest Income } \\
\hline Fee Income & $2,010,214$ & $2,155,642$ & $2,249,804$ \\
\hline Other Operating Income & $1,079,410$ & $1,118,627$ & $1,826,650$ \\
\hline Gain (Loss) on Disposition of Fixed Assets & $-1,212$ & $-2,318$ & $-3,483$ \\
\hline Other Non-Operating Income (Expense) & 25,164 & 5,299 & 462,443 \\
\hline NCUSIF Stabilization Income & $1,049,974$ & $1,049,974$ & $1,049,974$ \\
\hline TOTAL NON-INTEREST INCOME & $3,113,576$ & $3,277,250$ & $4,535,414$ \\
\hline \multicolumn{4}{|l|}{ Non-Interest Expense } \\
\hline Employee Compensation and Benefits & $3,738,257$ & $3,875,576$ & $4,211,879$ \\
\hline Travel and Conference Expense & 225,653 & 301,563 & 185,854 \\
\hline Office Occupancy Expense & 737,157 & 753,324 & 751,699 \\
\hline Office Operations Expense & $2,036,977$ & $2,212,504$ & $2,432,282$ \\
\hline Educational and Promotional Expense & 391,030 & 478,910 & 410,389 \\
\hline Loan Servicing Expense & 203,557 & 218,465 & 308,083 \\
\hline Professional and Outside Services & 40,355 & 41,292 & 54,036 \\
\hline Member Insurance & 11,859 & 10,243 & 291,906 \\
\hline Operating Fees (Examination /supervision fees) & 32,876 & 41,309 & 48,503 \\
\hline Miscellaneous Operating Expenses & 78,372 & 92,855 & 82,466 \\
\hline TOTAL NON-INTEREST EXPENSES & $7,496,093$ & $8,026,041$ & $8,777,097$ \\
\hline Net Income (Loss) Before NCUSIF Stabilization & $3,516,006$ & $3,516,006$ & $3,516,006$ \\
\hline NCUSIF Stabilization Expense & $1,049,974$ & $1,049,974$ & $1,049,974$ \\
\hline Net Income (Loss) & $2,241,013$ & $2,255,720$ & $2,466,032$ \\
\hline
\end{tabular}

Source: www.creditunions.com 
Exhibit 8: TEXAR Federal Credit Union - Statement Of Financial Condition

\begin{tabular}{|c|c|c|c|}
\hline Assets & 2,007 & 2,008 & 2,009 \\
\hline Cash & $21,613,759$ & $11,422,210$ & $14,736,550$ \\
\hline \multicolumn{4}{|l|}{ Investments } \\
\hline Available for Sale Securities & 0 & 0 & $15,896,936$ \\
\hline Held to Maturity & 0 & 0 & $1,087,032$ \\
\hline Membership Capital at Corp Credit Unions & $1,000,000$ & $1,000,000$ & 606,660 \\
\hline Other Investments in Corp Credit Unions & $6,500,000$ & $17,892,000$ & $6,669,000$ \\
\hline All Other Investments & $1,192,100$ & 976,000 & 664,300 \\
\hline TOTAL INVESTMENTS & $8,692,100$ & $19,868,000$ & $24,923,928$ \\
\hline \multicolumn{4}{|l|}{ Loans } \\
\hline Unsecured Credit Card Loans & $2,177,493$ & $2,230,195$ & $2,344,996$ \\
\hline All Other Unsecured Loans/Lines of Credit & $4,510,521$ & $4,571,087$ & $4,662,096$ \\
\hline New Vehicle Loans & $10,800,951$ & $14,176,793$ & $15,986,953$ \\
\hline Used Vehicle Loans & $38,020,664$ & $45,841,531$ & $53,209,675$ \\
\hline Total First Mortgage Loans/LOC & $54,971,691$ & $62,768,326$ & $63,772,536$ \\
\hline Total Other Real Estate Loans/LOC & 802,796 & 707,240 & 583,220 \\
\hline All Other Loans/Lines of Credit to Member & $31,448,685$ & $29,858,988$ & $27,914,822$ \\
\hline TOTAL LOANS & $142,732,801$ & $160,154,160$ & $168,474,298$ \\
\hline Less: Allowance for Loan Losses & 924,041 & 854,903 & $1,000,506$ \\
\hline \multicolumn{4}{|l|}{ Other Assets } \\
\hline Foreclosed and Repossessed Assets & 240,906 & 491,400 & 285,044 \\
\hline Land and Building & $6,662,152$ & $6,447,357$ & $6,207,159$ \\
\hline Other Fixed Assets & $1,124,309$ & $1,026,656$ & 800,161 \\
\hline NCUA Share Insurance Capitalization Deposit & $1,375,620$ & $1,588,173$ & $1,774,804$ \\
\hline Intangible Assets & $3,750,008$ & $3,589,927$ & $3,666,597$ \\
\hline Total Assets & $185,267,614$ & $203,732,980$ & 219,868,035 \\
\hline Liabilities, Shares And Equity & 2,007 & 2,008 & 2,009 \\
\hline \multicolumn{4}{|l|}{ Liabilities } \\
\hline Draws Against Lines of Credit & $22,000,000$ & $21,000,000$ & $10,500,000$ \\
\hline Accrued Dividends \& Interest payable on Shares & 454,971 & 396,683 & 245,480 \\
\hline Accounts Payable and Other Liabilities & $2,577,799$ & $2,385,273$ & $2,721,017$ \\
\hline Shares \& Deposits & $143,413,930$ & $160,874,391$ & $184,876,013$ \\
\hline \multicolumn{4}{|l|}{ Equity } \\
\hline Undivided Earnings & $13,598,625$ & $15,854,344$ & $18,320,377$ \\
\hline Regular Reserves & $3,222,289$ & $3,222,289$ & $3,222,289$ \\
\hline Other Comprehensive Income & 0 & 0 & $-17,141$ \\
\hline Total Liabilities, Shares And Equity & $185,267,614$ & $203,732,980$ & 219,868,035 \\
\hline
\end{tabular}

Source: www.creditunions.com

\section{CHALLENGES GOING FORWARD}

After more than 50 years of mostly stable operations, the credit union found itself in the midst of the recession that began in 2008. Although it faced an economic softening that was not as severe as economic indications in the national economy, TEXAR experienced a decline in loan demand for durable products, including homes and automobiles and the inability of some members to continue meet their payment obligations.

In addition, the failure of U.S. Central Federal Credit Union and Western Corporate (WesCorp) Federal Credit Union and the financial losses of Southwest Corporate Federal Credit Union had a negative impact on TEXAR. Similar to the Federal Deposit Insurance Corporation that insures losses in the banking industry, the National Credit Union Share Insurance Fund (NCUSIF) insures losses among credit unions. To help cover the losses of U.S. Central and WesCorp, TEXAR was assessed approximately $\$ 750,000$ and because of the losses at Southwest Corporate, it was assessed approximately $\$ 700,000$ 
In considering that, the board of directors and the management team of TEXAR Federal Credit Union believed there were several questions to answer before moving forward:

- How can TEXAR prepare itself for the uncertainty of projected continued soft economy assessments?

- How can TEXAR prepare for the uncertainty of additional NCUSIF assessments?

- $\quad$ Are there opportunities to introduce new financial services?

- $\quad$ Are there opportunities to offer existing financial services more efficiently?

\section{TEXAR Federal Credit Union: Instructor's Manual}

Intended Courses and Audience

The TEXAR Federal Credit Union case, with its emphases on strategic planning and effective management, is targeted primarily for undergraduate and graduate courses in management and strategic planning.

Teaching Plan

Our suggested teaching plan includes four elements: 1) evaluate the current market segments of TEXAR Federal Credit Union, 2) compare TEXAR to the industry, 3) evaluate TEXAR's financial trends using vertical analysis of the balance sheet, and 4) establish a strategic plan for moving forward.

\section{TEXAR Federal Credit Union: Assignment Questions and Analysis}

1. In developing a situation analysis, you need to synthesize several sources of information presented in the case, such as the primary research conducted by TEXAR FCU and secondary research from creditunions.com for TEXAR Federal Credit Union financial information and CUDATA.COM for industry data. Answer the following questions from information presented in the case:

a. What are the key market segments for TEXAR Federal Credit Union? Consider segmenting the total market according to geography, demographic variables, and usage behavior.

TEXAR Federal Credit Union has focused on the vehicle and mortgage segments of the credit union industry. Other possible segments are based upon demographics (gender, ethnics, and age), geography, and group type (individuals, employer, or group plans).

Most students will focus on one means of segmentation at a time when attempting to describe customers and potential customers. In this case, most will recognize loan type as a segment.

However, combining segmentation approaches gives a more complete picture.

b. Determining the financial health of the credit union is an important part of a situation analysis which requires an analysis of key financial ratios in comparison with those of the industry. There are several ways to choose an 'industry' comparison. One of the most common industry measures is based on the firm's primary SIC code or industry grouping. Another possible comparison would be with the firm's main competitors. Data for the credit union industry was given in the case. Compare TEXAR with the credit union industry and comment on some of the main differences.

The instructor can have the students compute various financial ratios for TEXAR or give them Exhibit 9 and ask for their analysis of the ratios. Students should note that TEXAR's delinquent loans as a percentage of total loans remained fairly constant for the last three years while the industry's rate has doubled going from .93\% in 2007 to $1.83 \%$ in 2009. 
Exhibit 9: TEXAR Federal Credit Union Statistics

\begin{tabular}{|c|c|c|c|}
\hline & 2007 & 2008 & 2009 \\
\hline \multicolumn{4}{|l|}{ Assets } \\
\hline Total Assets \$ & $185,267,614$ & 203,732,980 & $219,868,035$ \\
\hline Total Assets Growth (YTD) & & $9.97 \%$ & $7.92 \%$ \\
\hline Return On Assets (ROA) & $1.21 \%$ & $1.11 \%$ & $1.12 \%$ \\
\hline \multicolumn{4}{|l|}{ Net Worth } \\
\hline Net Worth \$ (undivided earnings + regular reserves) & $\mathbf{1 6 , 8 2 0 , 9 1 4}$ & $19,076,633$ & $21,542,666$ \\
\hline Net Worth Ratio (Net Worth/Total Assets) & $9.08 \%$ & $9.36 \%$ & $9.79 \%$ \\
\hline \multicolumn{4}{|l|}{ Total Loans } \\
\hline Total Loans (\$) & $142,732,801$ & $160,154,160$ & $168,474,298$ \\
\hline Total Loans (\$) Growth (YTD) & & $12.21 \%$ & $5.20 \%$ \\
\hline \multicolumn{4}{|l|}{ Loan Delinquency } \\
\hline Delinquent Loans & $1,042,830$ & $1,111,538$ & $1,314,506$ \\
\hline Delinquent Loans To Total Loans & $0.73 \%$ & $0.69 \%$ & $0.78 \%$ \\
\hline Charge offs & 796,628 & $1,021,715$ & $1,121,416$ \\
\hline Net Charge Offs To Avg Loan & $0.56 \%$ & $0.64 \%$ & $0.67 \%$ \\
\hline \multicolumn{4}{|l|}{ Deposits } \\
\hline Total Deposits $(\$)$ & $143,413,930$ & $160,874,391$ & $184,876,013$ \\
\hline Total Deposits (\$) Growth \% (YTD) & & $12.17 \%$ & $14.92 \%$ \\
\hline
\end{tabular}

c. When comparing data from different years or with the industry, using percentages is usually preferable. In vertical analysis, each amount in the balance sheet is expressed as a percent of total assets. Prepare a vertical analysis of TEXAR using data given in the case. Comment on your findings.

The completed vertical analysis is given in Exhibit 10. Areas with major changes in the percentages are highlighted with bold type. Students should note these areas in their discussion.

Exhibit 10: TEXAR Federal Credit Union - Statement of Financial Condition

\begin{tabular}{|c|c|c|c|}
\hline Assets & 2,007 & 2,008 & 2,009 \\
\hline Cash & $11.67 \%$ & $5.61 \%$ & $6.70 \%$ \\
\hline \multicolumn{4}{|l|}{ Investments } \\
\hline Available for Sale Securities & $-0-$ & $-0-$ & $\mathbf{7 . 2 3 \%}$ \\
\hline Held to Maturity & $-0-$ & $-0-$ & $0.49 \%$ \\
\hline Membership Capital at Corp Credit Unions & $0.54 \%$ & $0.49 \%$ & $0.28 \%$ \\
\hline Other Investments in Corp Credit Unions & $3.51 \%$ & $8.78 \%$ & $3.03 \%$ \\
\hline All Other Investments & $0.64 \%$ & $0.48 \%$ & $0.30 \%$ \\
\hline TOTAL INVESTMENTS & $4.69 \%$ & $9.75 \%$ & $11.34 \%$ \\
\hline \multicolumn{4}{|l|}{ Loans } \\
\hline Unsecured Credit Card Loans & $1.18 \%$ & $1.09 \%$ & $1.07 \%$ \\
\hline All Other Unsecured Loans/Lines of Credit & $2.43 \%$ & $2.24 \%$ & $2.12 \%$ \\
\hline New Vehicle Loans & $5.83 \%$ & $6.96 \%$ & $7.27 \%$ \\
\hline Used Vehicle Loans & $20.52 \%$ & $22.50 \%$ & $24.20 \%$ \\
\hline Total First Mortgage Loans/LOC & $29.67 \%$ & $30.81 \%$ & $29.00 \%$ \\
\hline Total Other Real Estate Loans/LOC & $0.43 \%$ & $0.35 \%$ & $0.27 \%$ \\
\hline All Other Loans/Lines of Credit to Member & $16.97 \%$ & $14.66 \%$ & $12.70 \%$ \\
\hline TOTAL LOANS & $77.04 \%$ & $78.61 \%$ & $76.63 \%$ \\
\hline Less: Allowance for Loan Losses & $0.50 \%$ & $0.42 \%$ & $0.46 \%$ \\
\hline \multicolumn{4}{|l|}{ Other Assets } \\
\hline Foreclosed and Repossessed Assets & $0.13 \%$ & $0.24 \%$ & $0.13 \%$ \\
\hline Land and Building & $3.60 \%$ & $3.16 \%$ & $2.82 \%$ \\
\hline Other Fixed Assets & $0.61 \%$ & $0.50 \%$ & $0.36 \%$ \\
\hline NCUA Share Insurance Capitalization Deposit & $0.74 \%$ & $0.78 \%$ & $0.81 \%$ \\
\hline Intagible Assets & $2.02 \%$ & $1.76 \%$ & $1.67 \%$ \\
\hline Total Assets & $100.00 \%$ & $100.00 \%$ & $100.00 \%$ \\
\hline
\end{tabular}


Exhibit 10: cont.

\begin{tabular}{|c|c|c|c|}
\hline Liabilities, Shares And Equity & 2,007 & 2,008 & 2,009 \\
\hline \multicolumn{4}{|l|}{ Liabilities } \\
\hline Draws Against Lines of Credit & $\mathbf{1 1 . 8 7 \%}$ & $10.31 \%$ & $4.78 \%$ \\
\hline Accrued Dividends \& Interest payable on Shares & $0.25 \%$ & $0.19 \%$ & $0.11 \%$ \\
\hline Accounts Payable and Other Liabilities & $1.39 \%$ & $1.17 \%$ & $1.24 \%$ \\
\hline Shares \& Deposits & $77.41 \%$ & $78.96 \%$ & $84.08 \%$ \\
\hline \multicolumn{4}{|l|}{ Equity } \\
\hline Undivided Earnings & $7.34 \%$ & $7.78 \%$ & $8.33 \%$ \\
\hline Regular Reserves & $1.74 \%$ & $1.58 \%$ & $1.47 \%$ \\
\hline Other Comprehensive Income & & & $-0.01 \%$ \\
\hline Total Liabilities, Shares And Equity & $100.00 \%$ & $100.00 \%$ & $100.00 \%$ \\
\hline
\end{tabular}

d. What is a strategy for TEXAR Federal Credit Union to respond to the economic downturn that began in 2008? Consider the local economy characteristics as compared to the national economic indicators for 2008 to the present.

Consider the advantage of a local economy whose downturn was significantly softer than that of the $U$. S. economy. Another consideration might be the credit union advantage in lending as commercial banks significantly tightened their lending criteria. TEXAR could emphasize in advertising its slogan, "Where Your Friends Are".

2. Review the Strengths/Weaknesses/Opportunities/Threats (SWOT) analysis and distinct competencies presented in the case. Identify distinct image and operational effectiveness or differentiation competencies of TEXAR Federal Credit Union. How sustainable is the competency?

Students should be aware that competitors cannot easily duplicate distinctive competencies. Distinctive competencies include human resources, strength of capital, and community image. The degree of difficulty in duplicating a distinct competency is an indication of how sustainable it is. In today's rapidly changing environment, maintaining and developing distinct competencies require continuous attention.

3. Does the TEXAR Federal Credit Union's mission statement adequately describe the current and future mission of the organization? If not, how would you change it?

Students should recognize that the current mission statement is straight forward and succinct. It may be adequate but the instructor may want to encourage students to look at mission statements of other financial institutions for comparison.

$4 \quad$ Establish a strategic plan for moving TEXAR Federal Credit Union forward.

The instructor should allow students the flexibility to establish varying objectives, goals, and strategies to move the organization forward. These different plans could become the basis for comparative student discussions.

\section{EPILOGUE}

By May, 2011, TEXAR Federal Credit Union's assets had increased to $\$ 261.326$ million and total loans were $\$ 173.5$ million. A new service fee schedule was adopted to better reflect cost of member services. Plans and incentives were also implemented to encourage members to use the credit union's online services when feasible. Live tellers inside the home office and in the drive-through lines were replaced by interactive monitors to attain a more efficient utilization of teller personnel. 


\section{AUTHOR INFORMATION}

Dr. Larry Davis is Dean of the College of Business and Professor of Economics and Management at Texas A \& M University-Texarkana. He received his BBA and MBA degrees from Texas A \& M University-Commerce and his $\mathrm{PhD}$ from the University of Arkansas-Fayetteville. His teaching resume includes Texas A \& M UniversityCommerce, Kilgore College, and the University of Arkansas-Fayetteville before becoming one of the original faculty members at Texas A \& M University-Texarkana in 1972. His areas of teaching include History of Economic Thought, Macroeconomics, Strategic Planning, and Human Resource Management. Dr. Davis is a renowned consultant working through the American Council on Education as a national coordinator and reviewer of corporate and military instructional and training programs. In that role, he has served almost 100 companies and military bases throughout the United States. He received the Distinguished Faculty Award at A \& M - Texarkana in 2008. E-mail: larryrdavis@msn.com

Dr. Joan Brumm is an Accounting Professor in the College of Business at Texas A\&M University-Texarkana. Dr. Brumm received her BS in Accounting from Wayne State University, her MBA from East Texas State University Texarkana, and her $\mathrm{PhD}$ (Accounting) from Louisiana State University. Dr. Brumm teaches financial accounting and tax. She is the editor of an online peer reviewed journal. Dr. Brumm is a CPA with over 20 years of experience prior to entering academe.

Dr. Charles McDonald is a professor of MIS and General Business at Texas A\&M University-Texarkana. Dr. McDonald received a MS in Management from East Texas State University - Texarkana, and his PhD in Computer Information Systems from Nova Southeastern University in 1996. He has a background in process control systems, electronic systems design, and software development. Dr. McDonald was vice president of Ed-Tech systems, Inc., Bryan Texas from 1989 to 1991 and president of Sandpiper Software Systems from 1991 to 2000. He has published several software packages that were distributed to more than 30 states and foreign countries. His current research interests include effective technology-based teaching methodologies, software solutions for identifying and commenting writing errors in research papers, an effective methodology for an upper-level fundamentals of database systems course, and factors affecting the enrollment and retention of Hispanic students in higher education. Dr. McDonald enjoys woodworking, baking, and gardening. 


\section{NOTES}

